\title{
XYLANASE PRODUCTION BY TRICHODERMA HARZIANUM RIFAI BY SOLID STATE FERMENTATION ON SUGARCANE BAGASSE
}

\author{
Maria Inês Rezende ${ }^{1,3,4 *}$; Aneli de Melo Barbosa ${ }^{2}$; Ana Flora Dalberto Vasconcelos ${ }^{2,4}$; Asae Sakurada Endo ${ }^{2}$ \\ ${ }^{1} \mathrm{CCB}$, Programa de Mestrado em Microbiologia, ${ }^{2}$ Setor CCE, Departamento de Bioquímica, \\ ${ }^{3}$ CCS-PALD, Setor de Toxicologia, Universidade Estadual de Londrina, Londrina, PR, Brasil. \\ ${ }^{4}$ Universidade Norte do Paraná, Londrina, PR, Brasil
}

Submitted: August 22, 2001; Returned to authors for corrections: November 22, 2001; Approved: February 25, 2002

\begin{abstract}
Sugarcane bagasse was used as substrate for xylanase production by means of a strain of Trichoderma harzianum Rifai isolated from decaying Aspidosperma sp. (peroba) wood. The bagasse was washed, dried, milled and wetted with minimal salts medium and the cultures grown at $28 \pm 2^{\circ} \mathrm{C}$ for 7 days. Two extraction methods were tested for enzyme recovery: (A) Tween 80, 0.1\% (v/v), in physiological saline, and (B) 50mM sodium acetate buffer, $\mathrm{pH} 5.0$, under agitation (180rpm) for 15, 30 and 60min. After a single extraction, both extraction methods recovered an average of $15 \mathrm{U} / \mathrm{ml}$ of xylanase activity, independent on the time of shaking. A second and third extraction recovered 10.4 and $6.6 \mathrm{U} / \mathrm{ml}$ xylanase, respectively. The effect of volume size for extraction, and sugarcane bagasse concentration, on xylanase production were also investigated. The growth profile of Trichoderma harzianum was followed over 20 days on 14\% (w/v) bagasse, and highest xylanase activity $(288 \mathrm{U} / \mathrm{ml})$ appeared on the seventh day. The enzymatic extract after precipitation with ammonium sulphate was submitted to electrophoresis on polyacrylamide gels and showed 4 protein-staining bands, one of which exhibited xylanase activity.
\end{abstract}

Key words: Trichoderma harzianum, xylanase, solid state fermentation, sugarcane bagasse

\section{INTRODUCTION}

Xylanases (E.C.3.2.1.8) belong to the group of hemicellulolytic enzymes (13), which are required for the hydrolysis of $\beta-1,4-$ xylans present in lignocellulosic materials. Several microorganisms have been reported as xylanolytic, and most of the bacteria, fungi and yeasts producing xylanases secrete the enzyme extracellularly. The ability of various Trichoderma spp. to produce xylanases, and how the addition of xylanases from Trichoderma harzianum aids in the hydrolysis of pretreated wood and in refining of cellulose was recently reviewed (25).

The use of xylanases in the utilization of lignocellulosic materials is under extensive study because of the production of xylose, which as a fermentation feedstock, is a raw material for single cell protein, or in the production of xylonic acid, xylitol and ethanol $(6,22)$. There is also much interest recently in the use of xylanases in the biobleaching of cellulose pulps, which decreases the demand for chlorines in conventional bleaching in paper making (4).

A strain of $T$. harzianum was isolated from decaying Aspidosperma sp. (Peroba) wood, and screened among 85 microorganisms as the best xylanase producer in submerged culture on sugarcane bagasse (SCB) as sole carbon source (3).

Bagasse is already used as solid fuel in the sugar mill to generate process steam, but 12 to 15 million tonnes per year, with the potential to become 25 million, remain as refuse and are either burnt or dumped (1). The advantages of using bagasse as substrate for bioconversion are that it has a high carbohydrate content (cellulose 50\% and hemicellulose 25\%), it is collected at the site of processing, it is regarded as a cheap substrate, and there is a constant supply generated

* Corresponding author. Mailing address: Rua Pio XII, 856/1304. 86020-381, Londrina, PR, Brasil. E-mail: mirezend@uol.com.br 
within the sugarcane industry $(12,20,22)$. Lignocellulosic substrates have been used for cellulolytic enzyme production in solid state fermentation (SSF) (9).

Most studies on the production of xylanases have been investigated in submerged liquid culture. There have been few reports on xylanase production in SSF using lignocellulosic wastes $(9,27,30)$ without chemical pretreatment or xylan addition. The purpose of this research was to evaluate xylanase and cellulase production by $T$. harzianum grown in SSF on sugarcane bagasse, and to standardise some parameters such as extraction system, time and volume size for recovering these enzymes.

\section{MATERIALS AND METHODS}

\section{Microorganisms}

The strain of Trichoderma harzianum Rifai was isolated from decaying Aspidosperma spp. wood in this laboratory. It was identified and classified by the Department of Mycology of UFPE (Recife-PE, Brazil).

\section{Preparation of sugar cane bagasse}

Sugarcane bagasse (SCB) was collected from a local sugar mill. It was prepared by exhaustive washing with distilled water, dried at $80^{\circ} \mathrm{C}$ for $24-48 \mathrm{~h}$, and milled ( 35 mesh).

\section{Chemicals}

Larchwood and Birchwood xylans were used as substrates for xylanase assays were obtained from Sigma (USA). All the others chemicals were of analytical grade.

\section{Cultivation}

T. harzianum was maintained on slants of Vogel minimum salts medium (29), xylose (1\%), and agar at $4^{\circ} \mathrm{C}$. Enzyme production was carried out under solid state culture. The microorganism was grown in test tubes containing Vogel minimum salts medium and xylose $(1 \% \mathrm{w} / \mathrm{v})$ as the carbon source, during 7 days, in order to get spores. These spores were scraped aseptically from the surface of agar plates, and suspended in sterile Tween 80 solution $(0.1 \% \mathrm{v} / \mathrm{v})$ in physiological saline, and this solution was used as inoculum. The T. harzianum was cultured in $125 \mathrm{ml}$ Erlenmeyer flasks on medium containing $2.5 \mathrm{~g}$ sugarcane bagasse and $25 \mathrm{ml}$ Vogel minimum salts medium $(10 \% \mathrm{w} / \mathrm{v})$, which was twice sterilised at $121^{\circ} \mathrm{C}$ for $20 \mathrm{~min}$, cooled and then inoculated with a $1 \mathrm{ml}$ spore suspension $\left(10^{7}-10^{8}\right.$ spores $\left./ \mathrm{ml}\right)$. The fungal cultures were incubated at $28 \pm 2^{\circ} \mathrm{C}$ over 7 days. Different sugarcane bagasse concentrations $(3.5,5,7,10,14,20$ and $28 \%$ w/v) were also studied under the same conditions. All cultures were developed in triplicate except the growing curve, which was performed in quadruplicate in the times specified. All the results presented represent mean values.

\section{Analytical Procedures}

The cultures were interrupted by addition of $50 \mathrm{mM}$ sodium acetate buffer, $\mathrm{pH} 5.0$, (extraction-A), or Tween $80(0.1 \% \mathrm{v} / \mathrm{v})$ in physiological saline (extraction-B). The solid mixture was shaken at $180 \mathrm{rpm}$ for 15,30 , and $60 \mathrm{~min}$. Different volumes sizes $(15,30$, 45, 60 and $90 \mathrm{ml}$ ) were tested with both extraction systems A and $B$ and shaken for $15 \mathrm{~min}$. They were centrifuged $(15 \mathrm{~min}$, $4.000 \mathrm{Xg}$ at $4^{\circ} \mathrm{C}$ ), the supernatants recovered and filtered at $4^{\circ} \mathrm{C}$ and used as the source of the enzyme solution. The same procedure was carried out for a control (culture medium without microorganism).

\section{Enzyme Assay}

Xylanase activity was assayed by measuring the reducing sugar released from xylan. The reaction mixture containing $0.1 \mathrm{ml}$ of Larchwood xylan solution $(1 \%, \mathrm{w} / \mathrm{v}), 0.05 \mathrm{ml}$ of $0.5 \mathrm{mM}$ sodium acetate buffer ( $\mathrm{pH} 5.0$ ), and $0.025 \mathrm{ml}$ diluted enzyme solution in a final volume of $0.5 \mathrm{ml}$, and were incubated at $50^{\circ} \mathrm{C}$ for $20 \mathrm{~min}$. The unit of xylanase activity was defined as the number of $\mu$ moles of reducing sugars formed (measured as xylose) per min under the assay conditions. The reducing sugars released were determined by the Somogyi (26) - Nelson (21) methods. Xylanase activity was also determined by the method outlined by Bailey et al. (2) for xylanase production in the growth profile. BXylosidase activity was determined according to Dekker (11). Filter paper cellulase activity (FPU) was determined by measuring the increase in reducing sugars liberated from the hydrolysis of Whatman $\mathrm{N}^{\circ} 1$ filter paper as described by Mandels et al. (19).

\section{Electrophoresis on polyacrylamide gels}

The electrophoresis was developed according to Davis et al. (10) using $7 \%$ polyacrylamide and $0.375 \mathrm{M}$ Tris- $\mathrm{HCl}$ buffer $(\mathrm{pH} 8.3)$ at $4^{\circ} \mathrm{C}$. A freeze dried xylanase sample $1 \%(\mathrm{w} / \mathrm{v})$ was mixed with $40 \%$ sucrose solution in the proportion 5:1, and 0.05 and $0.1 \mathrm{ml}$ were applied in tubes $(0.5 \times 8.0 \mathrm{~cm})$ containing the polyacrylamide gel. The electrophoretic run was developed for $1 \mathrm{~h}$ at $3 \mathrm{~mA}$ per tube. Bromophenol blue $0.1 \%(\mathrm{w} / \mathrm{v})$ was used as a marker. Following electrophoresis the gels were removed from the tubes and submerged by $1 \mathrm{~h}$ in a methanol: water: acetic acid (67:67:14) fixing solution, and stained with Comassie Brilliant Blue 0.1\%(w/v) solution in the same methanol solution during $2 \mathrm{~h}$. To eliminate the dye excess the gels were washed several times with acetic acid 5\% and methanol 7\%. The gels which were not stained were eluted with acetate buffer $50 \mathrm{mM}$ $\mathrm{pH} 5.0$ and then assayed to xylanase activity according to Bailey et al. (2).

\section{Other Methods}

Protein was determined by a modified Lowry method according to Hartree (17) using bovine serum albumin as the standard. Total sugars was determined by phenol sulphuric method (14) 


\section{RESULTS AND DISCUSSION}

Some enzymes produced under SSF have been recovered from the solid phase by treatment with water $(15,16,27)$, surfactant Tween $80(6,24)$, or by buffer solutions $(4,9,25)$. In this work, both extraction systems employed, acetate buffer (extraction-A) and Tween 80 (extraction-B), were found to be efficient in recovering xylanase under the conditions studied. The time of extraction $(15,30$ and $60 \mathrm{~min})$ had no influence on recovery of adsorbed enzyme from the solid medium (Fig. 1). The time required to remove enzyme from the solid substrate has been reported to range from $30 \mathrm{~min}$ (6) to up to $2 \mathrm{~h}$ under shaking conditions $(24,28)$. Alternatively, the enzyme has been recovered by simply filtering the solid suspension and collecting the filtrate (16).

Three consecutive extractions, after shaking for $15 \mathrm{~min}$, were performed and approximately $15.6,10.8$ and $6.6 \mathrm{U} / \mathrm{ml}$ of xylanase activity were obtained, independent of the extraction system used (Table 1). Considering that $100 \%$ of enzyme could be extracted with only three consecutive extractions, then $47 \%$ of xylanase was recovered from sugarcane bagasse during the first extraction. The $\mathrm{pH}$ of the control solution was 5.7 and increased to 6.6 in the extracted enzyme solution with extraction system $\mathrm{B}$. The $\mathrm{pH}$ variation demonstrated that the growth of Trichoderma harzianum and subsequent xylanase production, increased the $\mathrm{pH}$ of the culture fluid. The same variation in $\mathrm{pH}$ was not detected in the enzyme solution with the extraction-A system showing that the buffering capacity was maintained.

The average cellulase yield (FPU) was low at around $0.03 \mathrm{U} / \mathrm{ml}$. In the enzyme solutions extracted with the extraction-A system, the cellulase activity decreased with consecutive extractions. However, similar cellulase activities were obtained with the extraction-B system during three

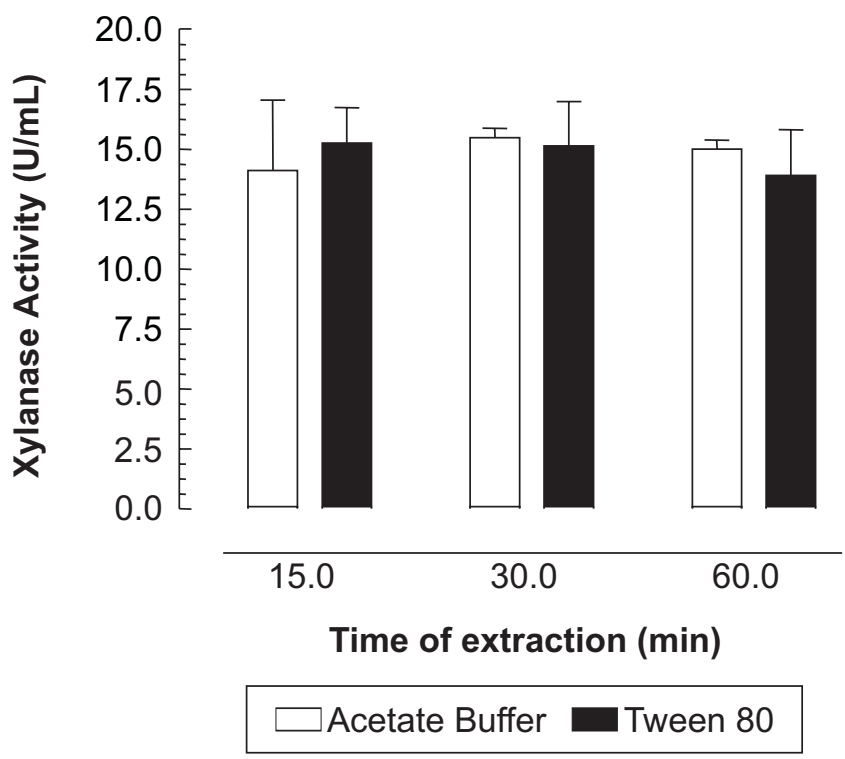

Figure 1. Influence of time and two extraction systems on xylanase recovery from the solid medium

extractions. These results, when compared with the xylanase activities, demonstrated that $T$. harzianum produced mainly xylanase under conditions of solid state culture. The specific activity of xylanase in the enzyme solutions was higher when the solid medium was extracted with extraction-A system, than when extraction-B system was used over three consecutive extractions. These results showed that both systems probably have different forms of action. The total and reducing sugar recovered in the extracts showed the same profile independent on the extraction system used (Table 1).

Table 1. Consecutive extractions of enzymes and sugars with $15 \mathrm{ml}$ of extraction systems A and B after shaking for $15 \mathrm{~min}$

\begin{tabular}{lcccccccc}
\hline & $\begin{array}{c}\text { Extraction } \\
\text { system }\end{array}$ & $\mathrm{pH}$ & \multicolumn{3}{c}{ Enzyme Activity } & \multicolumn{2}{c}{ Sugars } & $\begin{array}{c}\text { Protein } \\
(\mathrm{mg} / \mathrm{ml})\end{array}$ \\
\hline & & & $\begin{array}{c}\text { Xylanase } \\
(\mathrm{U} / \mathrm{ml})\end{array}$ & $\begin{array}{c}\text { Xylanase* } \\
(\mathrm{U} / \mathrm{mg})\end{array}$ & $\begin{array}{c}\text { FPU } \\
(\mathrm{U} / \mathrm{ml})\end{array}$ & $\begin{array}{c}\text { Total } \\
(\mathrm{mg} / \mathrm{ml})\end{array}$ & $\begin{array}{c}\text { Reducin } \\
(\mathrm{mg} / \mathrm{ml})\end{array}$ \\
\hline Control & $\mathrm{A}$ & 4.8 & ----- & ----- & ---- & 0.40 & 0.04 & 0.81 \\
& $\mathrm{~B}$ & 5.7 & ---- & ---- & --- & 0.44 & 0.06 & 0.87 \\
First & $\mathrm{A}$ & 4.8 & 15.5 & 12.2 & 0.03 & 1.22 & 0.59 & 1.27 \\
Extraction & $\mathrm{B}$ & 6.6 & 15.5 & 10.7 & 0.03 & 1.24 & 0.52 & 1.45 \\
Second & $\mathrm{A}$ & 4.7 & 10.4 & 13.0 & 0.02 & 0.81 & 0.44 & 0.80 \\
Extraction & $\mathrm{B}$ & 6.6 & 11.2 & 11.2 & 0.03 & 0.80 & 0.45 & 1.00 \\
Third & $\mathrm{A}$ & 4.7 & 6.6 & 12.2 & 0.01 & 0.51 & 0.26 & 0.54 \\
Extraction & $\mathrm{B}$ & 6.5 & 6.6 & 9.3 & 0.03 & 0.51 & 0.26 & 0.71 \\
\hline
\end{tabular}

A = 50mM sodium acetate buffer, $\mathrm{pH}$ 5.0; $\mathrm{B}=$ Tween 80; Xylanase* = Specific Xylanase Activity. 
When the volume of extraction system A was increased two, three, four and six times in relation to a single extraction using $15 \mathrm{ml}$, it was found that lower xylanase activity per $\mathrm{ml}$. However, more enzyme was recovered when the volume size was increased, although the increase in totals units activity enzyme was not proportional to volume size (Table 2). For example, when the volume of the extraction system was tripled only 1.2 times more enzyme was extracted in terms of totals units of activity. Comparing the total units of xylanase recovered with $45 \mathrm{ml}$ of extraction system-A with the same volume, but using $15 \mathrm{~mL}$ in each of three consecutive extractions, it was found that $275 \mathrm{U} / \mathrm{ml}$ could be extracted in a single extraction, while $1.488 \mathrm{U} / \mathrm{ml}$ were obtained with three consecutive extractions using lesser volume sizes (Table 3). These results demonstrated that less volume used consecutively can recover more enzyme than the same total volume used in a single extraction. When the results of xylanase activity from three consecutive extractions were compared using extraction system-A to system-B, in total units of enzyme, it was found that equal activities of enzymes were recovered independent on the extraction system used. These results confirmed data previously obtained from both extractions to recover xylanase in similar concentrations and in different times of shaking (Fig. 1). Higher cellulase activity was also obtained using three consecutive extractions rather than a single extraction. However, extraction-B system recovered more cellulase than the extraction-A system.

The highest enzyme titres for xylanase $(27.6 \mathrm{U} / \mathrm{ml})$ and cellulase $(0.26 \mathrm{U} / \mathrm{ml})$ were obtained with $14 \%$ (w/v) SCB after 7 days of culture (Table 4). Higher concentrations of SCB 20 and $28 \%(w / v)$ decreased xylanase production. These results showed that this probably happened because of some factors such as moisture and aeration of the cultures. According to Person et al. (23), high concentrations of solid substrates limit the agitation and consequently the mass transfer of oxygen. On the other hand, it is more difficult to extract the enzymes as
Table 3. Comparative extraction of enzymes produced by Trichoderma harzianum on sugar cane bagasse using either a single volume of $45 \mathrm{ml}$ of extraction system once, or $15 \mathrm{ml}$ three times consecutively.

\begin{tabular}{lrccccc}
\hline Extraction & \multicolumn{3}{c}{$\begin{array}{c}\text { Xylanase Activity } \\
(\mathrm{U} / \mathrm{ml})\end{array}$} & \multicolumn{3}{c}{$\begin{array}{c}\text { Cellulase Activity } \\
(\mathrm{U} / \mathrm{ml})\end{array}$} \\
\hline & $\left(^{*}\right)$ & $(* *)$ & $(* * *)$ & $(*)$ & $(* *)$ & $(* * *)$ \\
$\mathrm{A}$ & 16.2 & & & 0.03 & & \\
& 10.4 & 33.0 & 1.487 .7 & 0.02 & 0.06 & 2.7 \\
& 6.6 & 6 & & 0.01 & & \\
$\mathrm{~B}$ & 15.5 & & & 0.03 & & \\
& 11.0 & 33.0 & 1.487 .7 & 0.03 & 0.09 & 4.0 \\
$\mathrm{~A}(\S)$ & 6.6 & 6 & & 0.03 & & \\
\hline
\end{tabular}

$(*)=$ Consecutive extraction using $15 \mathrm{ml}$ of extraction system each time; $(* *)=$ Some of the activity of each extraction (total volume $45 \mathrm{ml}) ;(* * *)=$ Total units of enzyme.

higher as the concentration of substrate once the enzymes are stronger bound.

The relationship between soluble total sugar and reducing sugar in the control solutions was always higher than $5: 1(5 \mathrm{mg} /$ $\mathrm{ml}$ of soluble total sugar per $1 \mathrm{mg} / \mathrm{ml}$ of reducing sugar). The same relationship in the extracted enzyme solutions was always lower than 4:1 independent on the SCB concentration (Table 4). These data demonstrated that during the sterilisation of sugarcane bagasse, some extra sugar became soluble, probably the hemicellulose fraction, which is known to act as an inducer of xylanases by microorganisms (5).

The growth profile of T. harzianum on SCB in SSF and the xylanase production was followed over 20 days without addition of sterile water, and four flasks were harvested at $24 \mathrm{~h}$ intervals. Five flasks without microorganisms were collected on the $5^{\text {th }}, 10^{\text {th }}, 15^{\text {th }}$ and $20^{\text {th }}$ days and used as controls (Fig. 2). The peak of xylanase activity $(287.8 \mathrm{U} / \mathrm{ml})$ occurred at the $7^{\text {th }}$

Table 2. Xylanase extraction with different volume sizes of sodium acetate buffer.

\begin{tabular}{|c|c|c|c|c|c|c|c|c|c|c|}
\hline \multirow{4}{*}{$\begin{array}{l}\text { Volume } \\
(\mathrm{ml})\end{array}$} & \multirow{2}{*}{\multicolumn{2}{|c|}{$\begin{array}{l}\text { Xylanase } \\
\text { Activity }\end{array}$}} & \multirow{2}{*}{\multicolumn{2}{|c|}{$\begin{array}{l}\text { Cellulase } \\
\text { Activity }\end{array}$}} & \multicolumn{4}{|c|}{ Sugars } & \multicolumn{2}{|c|}{$\mathrm{pH}$} \\
\hline & & & & & \multirow{2}{*}{\multicolumn{2}{|c|}{$\begin{array}{l}\text { Total } \\
(\mathrm{mg} / \mathrm{ml})\end{array}$}} & \multirow{2}{*}{\multicolumn{2}{|c|}{$\begin{array}{r}\text { Reducing } \\
(\mathrm{mg} / \mathrm{ml}) \\
\end{array}$}} & \multirow[b]{3}{*}{$\mathrm{C} 1$} & \multirow{4}{*}{$\begin{array}{l}\mathrm{C} 2 \\
4.8\end{array}$} \\
\hline & \multirow{3}{*}{$\begin{array}{c}(\mathrm{U} / \mathrm{ml}) \\
15.8\end{array}$} & \multirow{3}{*}{$\begin{array}{c}\text { (U total) } \\
237.6\end{array}$} & \multirow{3}{*}{$\begin{array}{c}(\mathrm{U} / \mathrm{ml}) \\
0.03\end{array}$} & \multirow{3}{*}{$\begin{array}{c}\text { (U total) } \\
0.45\end{array}$} & & & & & & \\
\hline & & & & & $\mathrm{C} 1$ & $\mathrm{C} 2$ & $\mathrm{C} 1$ & $\mathrm{C} 2$ & & \\
\hline 15 & & & & & 0.40 & 1.22 & 0.04 & 0.59 & 4.8 & \\
\hline 30 & 6.4 & 192.6 & 0.04 & 1.20 & 0.30 & 0.80 & 0.04 & 0.37 & 5.6 & 5.8 \\
\hline 45 & 6.1 & 275.4 & 0.04 & 1.80 & 0.20 & 0.3 & 0.03 & 0.34 & 5.2 & 5.5 \\
\hline 60 & 5.1 & 306.0 & 0.05 & 3.00 & 0.16 & 0.50 & 0.02 & 0.27 & 5.1 & 5.2 \\
\hline 90 & 4.6 & 415.8 & 0.03 & 2.70 & 0.11 & 0.37 & 0.01 & 0.21 & 5.0 & 5.1 \\
\hline
\end{tabular}

$\mathrm{C} 1=$ Control solution; $\mathrm{C} 2=$ Cell-free culture fluid. 
Table 4. Effect of sugar cane bagasse concentration on xylanase production after 7 days of culture.

\begin{tabular}{|c|c|c|c|c|c|c|c|c|c|c|c|}
\hline \multirow{3}{*}{$\begin{array}{c}\text { [Bagasse] } \\
\%(w / v)\end{array}$} & \multicolumn{2}{|c|}{$\begin{array}{c}\text { Xylanase } \\
\text { Activity }\end{array}$} & \multirow{2}{*}{$\begin{array}{c}\text { Cellulase } \\
\text { Activity } \\
(\mathrm{U} / \mathrm{ml})\end{array}$} & \multicolumn{4}{|c|}{ Sugars } & \multirow{2}{*}{\multicolumn{2}{|c|}{$\begin{array}{l}\text { Protein } \\
(\mathrm{mg} / \mathrm{ml})\end{array}$}} & \multicolumn{2}{|c|}{$\mathrm{pH}$} \\
\hline & $(\mathrm{U} / \mathrm{ml})$ & (U total) & & \multicolumn{2}{|c|}{ Total $(\mathrm{mg} / \mathrm{ml})$} & \multicolumn{2}{|c|}{ Reducing $(\mathrm{mg} / \mathrm{ml})$} & & & & \\
\hline & & & & $\mathrm{C} 1$ & $\mathrm{C} 2$ & $\mathrm{C} 1$ & $\mathrm{C} 2$ & $\mathrm{C} 1$ & $\mathrm{C} 2$ & $\mathrm{C} 1$ & $\mathrm{C} 2$ \\
\hline $3.5 \%$ & 4.0 & 96.5 & 0.02 & 0.12 & 0.37 & 0.01 & 0.09 & 0.38 & 0.49 & 5.4 & 6.9 \\
\hline $5 \%$ & 6.1 & 140.8 & 0.02 & 0.20 & 0.51 & 0.02 & 0.15 & 0.48 & 0.62 & 5.6 & 6.9 \\
\hline $7 \%$ & 8.1 & 170.0 & 0.02 & 0.26 & 0.69 & 0.03 & 0.23 & 0.60 & 0.86 & 5.5 & 6.8 \\
\hline $10 \%$ & 10.3 & 170.3 & 0.03 & 0.37 & 0.93 & 0.06 & 0.3 & 0.78 & 1.15 & 5.4 & 6.5 \\
\hline $14 \%$ & 27.6 & 391.9 & 0.26 & 0.45 & 1.04 & 0.09 & 0.32 & 0.87 & 1.95 & 5.3 & 5.8 \\
\hline $20 \%$ & 19.4 & 329.5 & 0.26 & 0.47 & 1.26 & 0.07 & 0.34 & 0.78 & 1.93 & 5.2 & 6.0 \\
\hline $28 \%$ & 12.8 & 226.0 & 0.17 & 0.50 & 1.00 & 0.07 & 0.32 & 0.76 & 1.98 & 5.0 & 5.9 \\
\hline
\end{tabular}

$\mathrm{C} 1=$ Control solution.

day, however, from the $8^{\text {th }}$ to $14^{\text {th }}$ day the average production was $246.8 \mathrm{U} / \mathrm{ml}$, and after the $14^{\text {th }}$ day a strong decrease in the xylanase activity was observed. Although maximum xylanase production occurred at the $7^{\text {th }}$ day, the enzyme production profile showed a plateau from the $5^{\text {th }}$ to $14^{\text {th }}$ days of culture. The highest activity for b-xylosidase was at the $12^{\text {th }}$ day $(0.2$ $\mathrm{U} / \mathrm{ml}$ ). Comparing the results obtained by Lemos et al. (18), who studied enzyme production by Aspergillus awamori under SSF on sugarcane bagasse, A. awamori produced less xylanase $(30 \mathrm{U} / \mathrm{ml})$ and more b-xylosidase $(1.3 \mathrm{U} / \mathrm{ml})$, than $T$. hazianum when grown on the same substrate by SSF. The maximum cellulase production for Trichoderma hazianum was at $6^{\text {th }}$ day $(0.42 \mathrm{U} / \mathrm{ml})$.

Gel electrophoresis of the extracted enzyme showed 4 proteins bands, with only one exhibiting xylanase activity

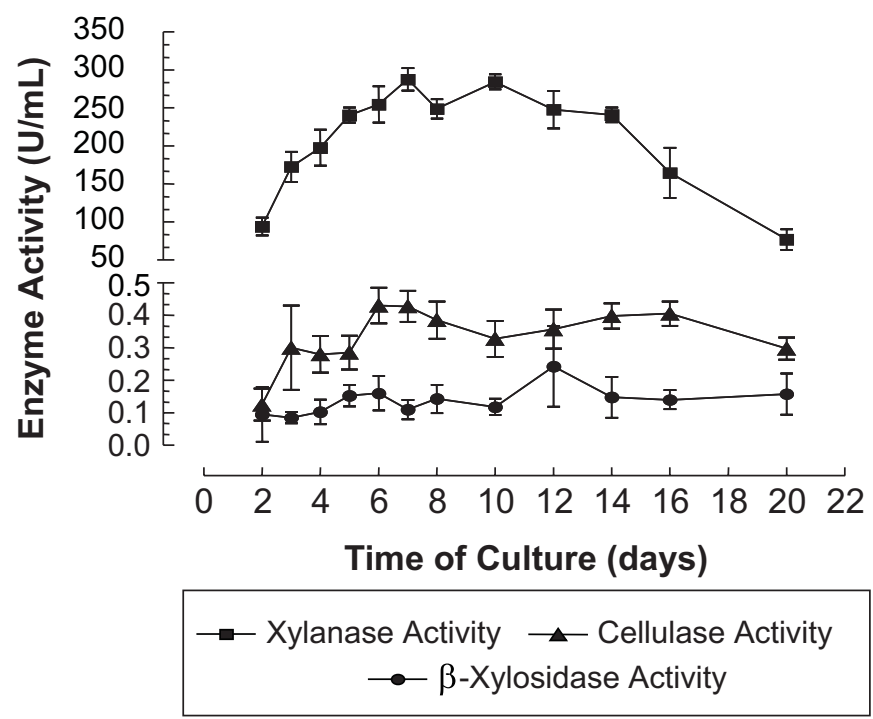

Figure 2. Xylanase, cellulase and b-xylosidase profiles by Trichoderma harzianum during 20 days of culture.
(Fig. 3). The other protein bands could be cellulase, b-xylosidase or different proteins produced by the fungus.

Then according to the results of these work when the $T$. harzianum was cultivated on sugar cane bagasse as sole carbon source it produced essencialy xylanase, once the b-xylosidase and cellulase activities were very low. Only some future studies on purification and caracterization of these enzymes will give more informations about these hydrolases and others enzymes involved in the native cell wall biodegradation of sugar cane bagasse by Trichoderma harzianum.

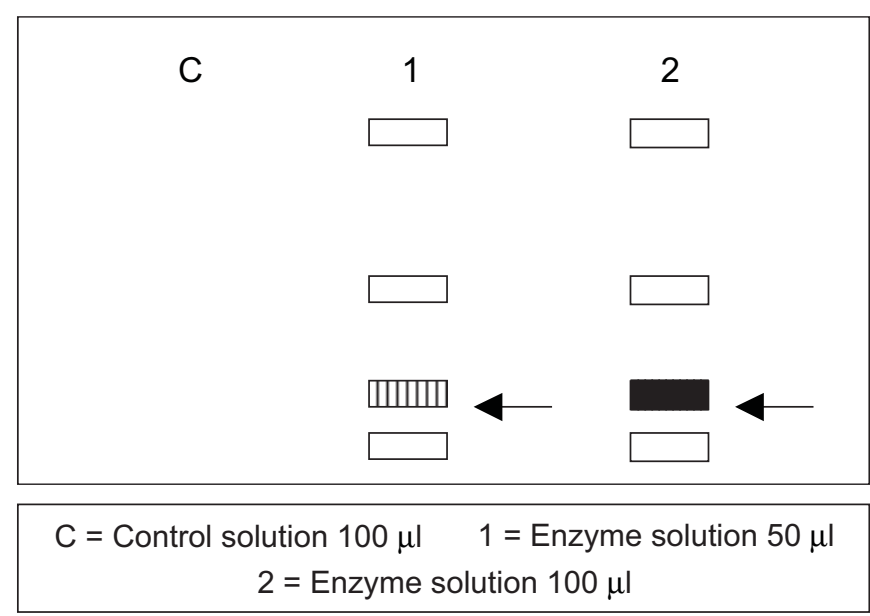

Figure 3. Diagram of the gel electrophoresis on polyacrylamide gels of the xyalanase solution $1 \%(\mathrm{w} / \mathrm{v})$. The arrows indicate the protein bands with xylanase activity.

\section{ACKNOWLEDGEMENTS}

We would like to thank Dr. Robert F.H. Dekker for his continuous interest and support of this study. This work was supported by funds from CPG-UEL and CNPq, Brazil. 


\section{RESUMO}

\section{Produção de xilanase pelo Trichoderma harzianum rifai por fermentação em fase sólida em bagaço de cana de açúcar}

Bagaço de cana-de-açúcar foi utilizado como substrato para a produção de xilanase pelo Trichoderma harzianum Rifai, isolado previamente de peroba (Aspidosperma $\mathrm{sp}$ ) em decomposição. Após ter sido lavado, seco e moído, o bagaço foi umedecido com meio mínimo de Vogel e autoclavado. Dois métodos de extração foram avaliados para recuperação da enzima: (A) Tween 80 0,1\% em salina fisiológica (v/v) e (B) tampão acetato pH $5(50 \mathrm{mM})$ sob agitação (180rpm) durante 15 , 30 e 60 minutos. Em média, foram recuperados $15 \mathrm{U} / \mathrm{ml}$ de atividade xilanásica com ambos os extratores, após uma única extração, independente do tempo de agitação. Uma segunda e terceira reextrações recuperaram 10,4 e 6,6U/ml, respectivamente. O efeito de diferentes volumes de extração e a concentração de bagaço de cana para a produção da xilanase também foram investigados. A curva de crescimento de Trichoderma harzianum foi avaliada durante 20 dias e a maior atividade xilanásica $(288 \mathrm{U} / \mathrm{ml})$ foi obtida no sétimo dia de cultivo. O extrato enzimático, após precipitação com sulfato de amônio, foi submetido à eletroforese em gel de poliacrilamida e apresentou 4 bandas de proteína, das quais apenas uma demonstrou atividade xilanásica.

Palavras-chave: Trichoderma harzianum, xilanase, fermentação em fase sólida, bagaço de cana

\section{REFERENCES}

1. Anuário Estatístico do Brasil. Ministério da Economia, Fazenda e Planejamento.Fundação Instituto Brasileiro de Geografia e Estatística - IBGE. Rio de Janeiro. 58:1-1,8-28, 1998.

2. Bailey, M.J.; Biely, P. and Poutanem, K. Interlaboratory testing of methods for assay xylanase activity. J. Biotechnol., 2: 257-270, 1992.

3. Barbosa, A.M. Seleção de microrganismos xilanolíticos e produção de xilanases pelo Trichoderma harzianum Rifai em bagaço de cana. Curitiba, 1992, 194p. (Tese de Doutorado Curso de Pós-Graduação em Bioquímica - UFPR).

4. Beg, Q.K.; Bhushan, B.; Kapoor, M. Hoondal, G.S. Enhanced production of a thermostable xylanase from Streptomyces sp QG11-3 and its application in biobleaching of eucalyptus kraft pulp. Enz. Microbial. Technol., 27: 459-466, 2000.

5. Beily, P. Microbial xylanolytic systems. Trends Biotechnol., 3(11): 286-290, 1985.

6. Biswas, S.R.; Mishra, A.K.; Nanda, G. Xylanase and b-xylosidase production by Aspergillus ochraceus during growth on lignocelluloses. Biotechnol. Bioeng., 31: 612-616, 1988.

7. Biswas, S.R.; Jana, S.C.; Mishra, A.K.; Nanda, G. Production, purification, and characterization of xylanase a hyperxylanolytic mutant of Aspergillus ochraceus. Biotecnol. Bioeng., 35: 244-251, 1990.
8. Cortez, E.V.; Pessoa Jr, A. Xylanase and b-xylosidase separation by fractional precipitation. Proc. Biochem., 35: 277-283,1999.

9. Couri, S.; Terzi, S.C.; Pinto, G.A.; Freitas, S.P.; Costa, A.C.A. Hydrolytic enzyme production in solid-state fermentation by Aspergillus niger 3T5B8. Proc. Biochem., 36: 255-261, 2000.

10. Davis, B.J. Disc Eletrophoresis. II Method and application to human serum proteins. Ann N.Y. Acad. Sci., New York. 121: 404-427, 1964.

11. Dekker, R.F.H. Bioconversion of hemicellulose: aspects of hemicellulose production by Trichoderma reesei QM-9414 and enzymic saccharification of hemicellulose. Biotecnol. Bioeng., 25: 1127-1146, 1983.

12. Dekker, R.F.H. Enzymatic hydrolysis of plant polysaccharides: substrates for fermentation. Braz. J. Med. Biol. Res., 22: 14411456, 1989

13. Dekker, R.F.H.; Richards, G.N. Hemicellulases: Their occurrence, purification, properties and mode of action. Ad. Carb. Chem. Biochem., 32: 277-352, 1976.

14. Dubois, M.; Gilles, K.A.; Hamilton, J.K. et al. Collorimetric method for determination of sugars and related substance. Anal. Chem., 28:350-356, 1956.

15. Ferreira, G.; Boer, C.; Peralta, R.M. Production of xylanolytic enzymes by Aspergillus tamarii in solid state fermentation. FEMS Microbiol. Lett., 173: 335-339, 1999.

16. Guimarães, A.G.; Linardi, V.R. Produção de celulases por fermentação sólida em diferentes substratos celulósicos. Arq. Biol. Tecnol., 31(3): 379-385, 1988

17. Hartree, E.F. Determination of protein: a modification of the Lowry method that gives a linear photometric response. Anal. Biochem., 48: 422-427, 1972.

18. Lemos, J.L.S.; Bon, E.P.S.; Santana, M.F.E.; Pereira Jr., N. Thermal stability of xylanases produced by Aspregillus awamori. Braz. J. Microbiol., 31: 206-211, 2000.

19. Mandels, M.; Andreotti, R.; Roche, C. Measurement of saccharifying cellulase. Biotechnol Bioeng. Symp., 6: 21-33, 1976.

20. Milagres, A.M.F. Alguns aspectos da regulação de beta-xilanases extracelulares de Penicillium janthinellum. Viçosa, 1988. (Tese de Mestrado Departamento de Biologia Geral da Universidade Federal de Viçosa).

21. Nelson, N.A. photometric adaptation of the Somogyi method for the determination of glucose. J. Biol. Chem., 153: 375-380, 1944.

22. Pandey, A.; Soccol, C.R.E.; Mitchel, D. New developments in solid state fermentation: I-bioprocess and products. Proc. Biochem., 35: 1153-1169, 2000.

23. Person, I.; Tjerneld, F.; Hahn-Hagerdal, B. Fungal cellulolytic enzyme production: A review. Proc. Biochem., 26: 65-74, 1991.

24. Silveira, F.Q.P.; Melo, I.S.; Filho, E.X.F. Carbohydrate-hydrolysing enzyme activity production by solid-state cultures of Trichoderma harzianum strains. Rev. Microbiol., 28: 152-156, 1997.

25. Silveira, F.Q.P.; Ximenes, F.A.; Cacais, A.O.G.; Milagres, A.M.F.; Medeiros, C.L.; Puls, J. E Filho, E.X.F. Hydrolysis of xylans by enzyme system from solid cultures of Trichoderma harzianum strains. Braz. J. Med. Biol. Res., 32: 947-952, 1999.

26. Somogyi, M. A new reagent for the determination of sugars. J. Biol. Chem., 160: 61-68, 1945.

27. Souza, D.F.; Souza, C.G.M.; Peralta, R.M. Effect of easily metabolizable sugars in the production of xylanase by Aspergillus tamarii in solid-state fermentation. Proc. Biochem., 36: 835-83, 2001.

28. Urieta, A.B.; Toma, M.; Park, Y.K. Estudo comparativo da produção de celulase fúngica por fermentação submersa e por cultura semisólida. Rev. Bras. Tecnol., 6: 181-188, 1975.

29. Vogel, H.A. A convenient growth medium for Neurospora crassa. Genet. Bull., 13: 42-43, 1956.

30. Yang, X.; Cheng, H.; Gao, H.; Li, Z. Bioconversion of corn straw by coupling ensiling and solid-state fermentation. Biores. Technol., 78: 277-280, 2001. 